\title{
SURVEY OF DUCHENNE TYPE AND CONGENITAL TYPE OF MUSCULAR DYSTROPHY IN SHIMANE, JAPAN ${ }^{1}$
}

\author{
Kenzo Takeshita, * Kunio Yoshino, ${ }^{*}$ Tadashi Kitahara, ${ }^{*}$ \\ Toshio NAKashima, ** and Noriko KATO*** \\ *Division of Child Neurology, Brain Research Institute, \\ Tottori University School of Medicine, Yonago, Japan \\ **National Matsue Hospital, Matsue, Japan
}

\begin{abstract}
Summary Duchenne muscular dystrophy and congenital muscular dystrophy (Fukuyama type) were analyzed clinically, genetically and epidemiologically in Shimane Prefecture in the Western Honshu Island of Japan. Cases were collected from all available sources and the diagnosis was reexamined by our group, yielding a total of 83 patients with various myopathies.

Thirty-two patients with Duchenne muscular dystrophy were found. Their clinical manifestations were not different from cases occurring elsewhere in Japan. The incidence rate of this type was $20.8 \times 10^{-5}$. Parental consanguinity of the cases was noted in $18.5 \%$, considerably higher than control families.

As to the Fukuyama type of congenital muscular dystrophy, 11 patients were identified. The incidence rate was $5.60 \times 10^{-5}$. There was no doubt that an autosomal recessive pattern of inheritance was involved in these patients. The gene frequency was estimated as 0.0075 .
\end{abstract}

\section{INTRODUCTION}

Duchenne muscular dystrophy and congenital muscular dystrophy are the most common and clinically severe myopathies in childhood. According to Araki (1967), the prevalence rate of progressive muscular dystrophy pooling all types is $2.6-5.5 \times$ $10^{-5}$ in Japan, of which $44.5 \%$ is classified as Duchenne type. Although far less frequent than Duchenne type, a congenital type of muscular dystrophy first reported by Fukuyama et al. (1960) is widely known among Japanese pediatricians. This type is supposed to be recessively heritable, but there is no report about its frequencies in the population.

The present report describes clinical, genetic and epidemiologic patterns of the stated two types of muscular dystrophy in Shimane Prefecture, located in Western Honshu Island of Japan.

Received July 23, 1977

1 This paper was partially presented at the 18 th Annual Meeting of the Japanese Society of Pediatric Neurology, June 16, 1976. 


\section{MATERIALS AND METHODS}

In order to find patients possibly suffering from myopathies, questionnaires were sent to all the nurse-teachers in 118 infant schools, 318 primary schools and 141 junior high schools in Shimane Prefecture, asking whether there were individuals who had motor troubles like myopathies. In addition, records in two public institutions for children, three hospitals for handicapped children and two protecture institutions in Shimane Prefecture were also surveyed for similar cases. The population survey was done from January, 1975 through June, 1975. The provisional cases with suspected myopathy were collected from people of all ages.

All patients were examined neurologically and electromyographically and serum levels of creatine-phosphokinase (CPK) were determined. Muscle biopsies were made for definite diagnosis in some cases. The medical examination was finished in November, 1975.

\section{RESULTS}

The questionnaires were all returned and yielded 104 provisional cases, whereas 58 cases were found in the record surveys. Reevaluation of the diagnosis revealed that a total of 83 patients were suffering from various types of muscular dystrophy as seen in Table 1. The population in Shimane Prefecture was 768,876 in 1975 . The prevalence rate of muscular dystrophy, all types pooled, was approximately $10.7 \times$ $10^{-5}$ for November, 1975.

\section{Duchenne muscular dystrophy}

Thirty-two Duchenne patients were found. All cases were males, their age ranged mostly $5-19$.

Clinically, (1) the mean age of onset was $4.7 \pm 1.37$ years, (2) all patients except one manifested the disease with gait disturbances as initial symptoms, (3) 23 bedpatients became unable to walk between 9-15 years of age, (4) pseudohypertrophy was seen in all patients, (5) subnormal intelligence was noted in 21 patients.

Table 1. Numbers of patients with muscular dystrophy by type and sex and numbers of families of patients exhaustively collected in Shimane Prefecture, November, 1975.

\begin{tabular}{|c|c|c|c|c|c|c|c|c|}
\hline & \multirow{2}{*}{$\begin{array}{c}\text { Duchenne } \\
\text { type }\end{array}$} & \multicolumn{2}{|c|}{ Congenital type } & \multirow{2}{*}{$\begin{array}{l}\text { Limb- } \\
\text { girdle } \\
\text { type }\end{array}$} & \multirow{2}{*}{$\begin{array}{c}\text { Facio- } \\
\text { scapulo- } \\
\text { humeral } \\
\text { type }\end{array}$} & \multirow[b]{2}{*}{ Others } & \multirow{2}{*}{$\begin{array}{l}\text { Myotonic } \\
\text { dystrophy }\end{array}$} & \multirow[b]{2}{*}{ Tota } \\
\hline & & $\begin{array}{c}\text { Fukuyama } \\
\text { type }\end{array}$ & Others & & & & & \\
\hline Male & 32 & 5 & 4 & 10 & 1 & 1 & 2 & 54 \\
\hline Female & 0 & 6 & 1 & 12 & 2 & 2 & 5 & 29 \\
\hline Total & 32 & 11 & 5 & 22 & 3 & 3 & 7 & 83 \\
\hline $\begin{array}{l}\text { No. of } \\
\text { families }\end{array}$ & 27 & 7 & 5 & 15 & 3 & 3 & 3 & 63 \\
\hline
\end{tabular}


Table 2. Incidence of Duchenne muscular dystrophy among male live-births between 1956-1970.

\begin{tabular}{cccc}
\hline $\begin{array}{c}\text { Year } \\
\text { of birth }\end{array}$ & $\begin{array}{c}\text { No. of male } \\
\text { live-births }\end{array}$ & $\begin{array}{c}\text { No. of } \\
\text { patients }\end{array}$ & $\begin{array}{c}\text { Incidence } \\
\text { rate }\left(\mathbf{1 0}^{-5}\right)\end{array}$ \\
\hline $1956-1960$ & 26,992 & 7 & 259 \\
$1961-1965$ & 29,593 & 4 & 135 \\
$1966-1970$ & 34,572 & 8 & 231 \\
\hline Total & 91,157 & 19 & 208 \\
\hline
\end{tabular}

Table 3. Consanguineous marriages among parents of Duchenne muscular dystrophy and Fukuyama type congenital muscular dystrophy.

\begin{tabular}{llcc}
\hline & Duchenne type & Congenital type & Control in Shimane \\
\hline No. of families & 27 & 7 & 480 \\
\hline First-cousins & 3 & 1 & $12(2.5 \%)$ \\
Half-cousins & 2 & 1 & $15(3.1 \%)$ \\
Second-cousins & 0 & 0 & $3(0.6 \%)$ \\
\hline Total & $5(18.5 \%)$ & $2(28.6 \%)$ & $30(6.2 \%)$ \\
\hline
\end{tabular}

When plotted against a map of the prefecture, the addresses of the patients revealed no focus of high incidence. Incidence rate of this type among the 91,157 male aged between 5 and 19 (born in 1956-1970 inclusive) was $20.8 \times 10^{-5}$ or about 1 in 4,800 male youths (Table 2). The rates did not change by year periods of the birth.

All the patients were comprised in 27 families. Consanguinity up to second cousin mating was observed in 5 pairs of the parents (Table 3). Consanguinity rate was $18.5 \%$ and the coefficient of inbreeding was 0.0092 . According to the family patterns of the patients, 4 mothers were definite carriers, whereas 3 were probable and the remaining 20 were possible carriers.

Fukuyama-type congenital muscular dystrophy

A total of 16 patients were classified as having congenital myopathies. Eleven of the 16 patients, 5 males and 6 females, belonged to the group of Fukuyama-type congenital muscular dystrophy.

Clinically, (1) all the patients were unable to walk alone, (2) muscular weakness were severe and proximally dominant, (3) facial muscular involvement, joint contractures and severe mental retardation were noted in all the patients.

The geographical distribution of 11 patients revealed no particular pattern.

Ten of 11 patients were aged from 5 to 19 . Incidence of this group among a total of 178,457 population aged between 5 and 19 (born in 1956-1970) was $5.60 \times 10^{-5}$ or about 1 in 18,000 youths (Table 4 ).

All the patients were comprised in 7 families. Consanguinity up to second cousin mating or more was observed in 2 pairs of parents (Table 3). Consanguinity rate was $29.6 \%$ obviously elevated than the proportion in control parents from the same 
Table 4. Incidence of Fukuyama type congenital muscular dystrophy among live-births between 1956-1970.

\begin{tabular}{cccc}
\hline $\begin{array}{c}\text { Year } \\
\text { of birth }\end{array}$ & $\begin{array}{c}\text { No. of } \\
\text { live-births }\end{array}$ & $\begin{array}{c}\text { No. of patients } \\
\text { (male:female) }\end{array}$ & $\begin{array}{c}\text { Incidence } \\
\text { rate }\left(10^{-5}\right)\end{array}$ \\
\hline $1956-1960$ & 52,296 & $5(3: 2)$ & 956 \\
$1961-1965$ & 58,285 & $4(0: 4)$ & 686 \\
$1966-1970$ & 67,876 & $1(1: 0)$ & 179 \\
\hline Total & 178,457 & $10(4: 6)$ & 560 \\
\hline
\end{tabular}

population. Of a total of 18 sibs in 7 families 11 were patients. Segregation ratio, which was calculated according to Weinberg's formula, was found to be 0.0364 , although its validity was questionable due to a small sample size.

\section{DISCUSSION}

Patterns of Duchenne type as well as Fukuyama type of muscular dystrophy, particularly their frequencies, were evaluated in Shimane Prefecture in Japan.

As to the frequency of Duchenne type diversified figures have been published. A low incidence, namely 1 in 100,000 live births i.e., 1 in 50,000 live-born male infants, was mentioned by Pearson (1973). Morton and Chung (1959) estimated the incidence for Wisconsin to be 1 in 3,000 live births. A similar figure can be computed from the studies of Stephens and Tyler of Utah (1951).

Zellweger and Antonik (1975) also found 1 case in 3,300 male live births. In Japan, Miyazaki (1963) estimated the prevalence rate for Fukuoka City to be $4 \times 10^{-5}$, which was similar to those from the studies of Walton (1955). From records in the many public hospitals, Araki (1967) estimated the prevalence rate of progressive muscular dystrophy in Japan to be $2.6-5.5 \times 10^{-5}$, of which $44.5 \%$ had Duchenne muscular dystrophy. According to our work in Shimane Prefecture, the incidence of Duchenne muscular dystrophy was $20.8 \times 10^{-5}$ or about 1 in 4,800 male youths. Assuming that all patients under the age of 19 had survived the disease, the estimates might be similar to the incidence among male live births.

Duchenne muscular dystrophy is generally considered to be inherited as an Xlinked recessive trait. However, there have been a few reports of cases purportedly transmitted by an autosomal recessive gene. Miyoshi et al. (1975) estimated from their pooled data that X-linked recessive, new mutation and autosomal recessive types occurred with the proportion roughly $68: 25: 14$. The consanguinity rate of $18.5 \%$ encountered in the parents of our Duchenne patients was remarkably higher than $6.3 \%$ in the control families. This may probably indicate that simple recessive cases were included in our material which were indistinguishable from X-linked Duchenne patients.

Congenital muscular dystrophy reported by Fukuyama et al. (1960) is the most common type of congenital dystrophies observed in Japan. This is characterised 
by (1) transmission by an autosomal recessive gene, (2) slow progression, (3) proximal muscular weakness with facial muscular involvement, (4) early onset of joint cotractures, and (5) frequent mental retardation. All the patients so diagnosed in Shimane Prefecture exhibited typical picture of this group.

Its incidence rate was estimated as $5.60 \times 10^{-5}$ or about 1 in 18,000 youths, but as some patients might posssibly died without surviving until the age of 5 , this figure is considered to be low. No data pertaining to the frequency of this disease was reported thus far.

The consanguinity rate of $28.6 \%$ in Fukuyama type was remarkably higher. The both sexes were nearly equally affected, and although acceptable segregation ratio was not available, there was little doubt that an autosomal recessive pattern of inheritance was involved in these patients. Based on records in many public hospitals, Kondo et al. (1974) made a genetic analysis of the disease and accepted the stated pattern of inheritance. They estimated the gene frequency of this type to be $0.94-1.56 \%$.

\section{REFERENCES}

Araki, S. 1967. Myopathy in Japan. Special Issue of the 17th Annual Meeting of Japanese Society of Medicine, Vol. 4, pp. 1014-1015 (in Japanese).

Fukuyama, Y., Kawazura, M and Haruna, H. 1960. A peculiar form of congenital progressive muscular dystrophy. Paediatr. Univ. Tokyo 4: 5-8.

Kondo, K., Segawa, M and Fukuyama, Y. 1974. Genetics of congenital muscular dystrophy (Fukuyama). The 16th Annual Meeting of the Japanese Society of Pediatric Neurology.

Miyazaki, T. 1963. A epidemiological, genetic and clinical study on the progressive muscular dystrophies. Fukuoka Acta Medica 54: 1007-1038.

Miyoshi, K., Tada, Y., Sasaki, N., Iwasa, M. and Kawai, H. 1975. Genetics of muscular dystrophy. Neurol. Med. 3: 113-122 (in Japanese).

Morton, N. E. and Chung, C. S. 1959. Formal genetics of muscular dystrophy. Am. J. Human Genet. 11: 360-366.

Pearson, C. M. 1973. Childhood pseudohypertrophic muscular dystrophy. In Birth Defects, Atlas and Compendium (D. Bergsma, ed.), Williams \& Wilkins Co., Baltimore, p. 257.

Stephens, F. E. and Tyler, F. H. 1951. Studies in disorders of the muscle. Am. J. Human Genet. 3: 111-116.

Walton, J. N. and Gardner-Medwin, D. 1969. Progressive muscular dystrophy and the myotonic disorders. In Disorders of Voluntary Muscle (J. N. Walton, ed.), 2nd. ed., Churchill, London, p. 455.

Walton, J. N. 1955. On the inheritance of muscular dystrophy. Ann. Human. Genet. 20: 1-7.

Zellweger, H. and Antonik, A. 1975. Newborn screening for Duchenne muscular dystrophy. Pediatrics 55: 30-34. 